\title{
Effect of The Combination of Organic and Inorganic Fertilizers on The Growth and Production of Melons (Cucumis Melo L)
}

\author{
Junaidi $^{\mathbf{a}^{*}}$ and Yukarie Ayu Wulandari ${ }^{\mathrm{b}}$ \\ ${ }^{a}$ Department of Agribusiness, Faculty Science and Technology \\ Syarif Hidayatullah State Islamic University Jakarta \\ Tangerang Selatan, Indonesia \\ ${ }^{b}$ Faculty of Agriculture, University of Muhammadiyah Jakarta \\ *Email: junn_agro@yahoo.com
}

\begin{abstract}
Melon is one of the horticultural products consumed in the form of fresh and processed fruit The demand for melon is quite high. Melon production in Indonesia is fluctuated, which decreased in 2010 and then increased in 2011 and 2012 and again decreased in 2013. One of the causes of the decrease in melon productivity is the use of inorganic fertilizer continuously for the long term. To increase growth and fruit production can be carried out with good managements and handlings, one of them is with the use of organic fertilizers. The use of organic fertilizer can increase productivity in a relatively long time. Therefore, research needs to be done by combining the use of organic and inorganic fertilizers to increase melon productivity. The research was conducted using 100\% NPK fertilizer, goat manure + NPK 50\%, caw manure + NPK 50\%, 50\% chicken manure and compost fertillizer + NPK 50\%. The results indicated that the combination of organic and inorganic fertilizers significant effect on melon fruit weight but not significant effect on leaves number, leaves length, leaves width, first flower time, fruit circumference and fruit sugar content. The combination of chicken manure with $50 \%$ NPK gave the highest yield on leaves number, leaves length, leaves width and first flower melon time but not significantly different from other treatments and gave the highest yield on melon fruit weight and significantly different from other treatments. The combination of compost fertilizer with NPK 50\% gave the highest yield on fruit circumference and melon fruit sugar but not significantly different from other treatments.
\end{abstract}

Keywords: Fertilizer combination, Growth, Melon, Production

\section{Introduction}

Melon is one of the horticultural products consumed in the form of fresh and processed fruit. Melon is one of the many fruits consumed by society as well [1]. Melon (Cucumic melo L) is an annual fruit crop that belongs to the Cucurbiataceae family. Melon has a high commercial value in Indonesia with wide and varied market ranges, ranging from traditional markets, modern markets, restaurants and hotels [2].
Melon production in Indonesia is fluctuated, where in 2009 melon production was as much as 85.861 tons and decreased in 2010 to 85,161 tons. The production of melon has increased in 2011 and 2012 by 103,800 tons and 125,447 tons and decreased again in 2013 to 112,439 tons [3]. The decrease of melon production is caused by the continuous use of chemical fertilizers for the long term.

Increased growth and fruit production can be carried out with good managements and handlings. Handling solutions that are considered effective in increasing the growth and production of melon fruit is to cultivate melons with the use of organic fertilizers. However, the use of organic fertilizer can increase productivity as well in a relatively longer period of time compared to the use of inorganic fertilizers [4]. Based on several arguments above, it is necessary to perform melon cultivation by combining the use of organic and inorganic fertilizers. Research on the combination of NPK fertilizer with various organic fertilizers needs to be carried out to find out the combination of fertilizer that gives the best effect to the growth and production of melon.

\section{Research Method}

The study was conducted in March to May 2016. The experiment was conducted in the experimental garden of Faculty of Agriculture, University of Muhammadiyah Jakarta which is at $25 \mathrm{~m}$ above sea level with latosol type of soil. Materials used in this research include melon seeds, NPK (16:16:16), $\mathrm{KCl}$, cow manure, chicken manure, goat manure, compost, organic pesticides, polybag size $50 \times 50 \mathrm{~cm}$, bamboo hydroponic, wire rope, paper labels, fruit enclosures and plastic bags. Tools used include hoe, machete, knife, pliers, scales, spoon, refractrometer, and meter.

The research was carried out using the Randomized Complete Group Design (RKLT) with the following treatments: P0 (NPK 100\% as recommended), P1 (goat manure + NPK 50\%), P2 (cow manure + NPK $50 \%$ ), P3 (fertilizer Chicken coop + NPK 50\%) and P4 (compost + NPK 50\%). Each treatment was repeated five times so that there were 25 experimental units. Each experiment consisted of two plants so that 50 plants were observed. The data obtained were then analyzed using an 
F-test and performed further test analyses by using BNJ test at $5 \%$ level.

Planting media were prepared a week before planting without using any basic fertilizer. The media used was experimental land of Faculty of Agriculture, which has been loosed first, then put into polybag $50 \times 50 \mathrm{~cm}$. The melon seeds were soaked in warm water for two hours, then the seeds were drained after being immersed in a wet or damp towel for 17 hours and then planted. Each polybag was planted 3 seeds, after the plant was $1 \mathrm{mst}$, thinning was carried out by leaving one of the best plants.

Fertilization was given according to treatment on each plant. Goat manure, cows, chickens and composted fertilizers were given when planting with a dose of 5 tons/ha. NPK Fertilizer (16:16:16) was given gradually, ie at age 14, 24, 34, 44 days after planting (hst) with a dose of $10 \mathrm{~g} /$ plant. $\mathrm{KCl}$ fertilizer was given at age 55 hst with dose $1 \mathrm{~g} /$ plant [2]. Watering, controlling plant pest organisms and installation of bamboo hydroponic were carried out in accordance with the circumstances in practice. Pruning was carried out when the plants begin flowering, covering was carried out at 1 week after the antesis. Harvesting was carried out when the fruit was ripe physiologically. The variables observed in this study were in a vegetative phase include leaf number, leaf length and leaf width, while in a generative phase include first flower time, fruit weight, fruit circumference and fruit sugar content.

\section{Results And Discussion \\ 3.1 General Overview}

The research was conducted from March to May 2016. Based on weather data obtained from the Meteorology, Climatology and Geophysics Region II Ciputat indicated that the average daily temperature in March was rainfall of $1800 \mathrm{~mm}$ at a temperature of $28.1{ }^{\circ} \mathrm{C}$ and humidity of $83.5 \%$. On April instead of the average rainfall was 307.2 $\mathrm{mm}$ with a temperature of $28.5^{\circ} \mathrm{C}$ and humidity of $82.0 \%$. In May rainfall was $260.3 \mathrm{~mm}$ with temperature $28{ }^{\circ} \mathrm{C}$ and humidity $81 \%$. According to Tim Bina Karya Tani (2010) melon plants grow well at an altitude of $300-900 \mathrm{~m}$ above sea level. Melon plants require full sunlight in their growth. The optimal temperature for melon growth is between $25-30{ }^{\circ} \mathrm{C}$. Continuous downpours can damage the growth and development of plants. High humidity causes melon plants easily attacked by disease. Melon plants will grow optimally if planted during the dry season. when seen growing requirements, general requirements are not met melon plant grows from the side elevation, the growing season, rainfall and humidity. Environmental conditions that are not in accordance with the requirements of growing melon plants, leading plants growth is not optimal, attacked by pests and diseases. At the time the plant was three weeks after planting (mst), plants were attacked locusts (Locasia migradoria), leaf borer (Liriomyza huidobrensis), caterpillar inch (Chrysodeixis chalcites), caterpillars (Macrothylacia rubies) and ladybugs (Coccinella arcuata). The pest attacks resulted in some plant leaves leaf perforated with torn edges, some leaves curled and turned yellow. At the time the plants begin to bloom, the rain occured continuously causing flowers and fruit to fall out. Only a few would resist and develop into fruit. Melon fruit was attacked by fruit flies (Bactrocera, sp) so that the fruit rot.

Diseases that attacked melon plants such as stem blight (gummy stem bligt). This disease is caused by the fungus Mycophaerekka melonis (Passerini) Chiu et Walker. The symptoms was the base of the stem attacked first such as oil-dipped then out the brownish mucus then the plants wither and die. The leaves of the infected plants would dry up, then followed by flowers and fruit then fall out. Plants were also attacked by bacterial wilt disease. This disease was caused by bacteria Erwina tracheiphila E.F.Sm with symptoms leaves and branches turned wither, creeping, and yellow on the leaves, then dried and eventually died. Leaves of the plants wilted one by one, although the color remained green, then the plant withered overall. If the stem is cut across, it would release a thick and sticky white mucus. Pests and infectious diseases were controlled using biopesticides which was applied every two days with different spraying times.

\subsection{Growth}

Based on the result of analysis of variance indicated that the combination of organic and inorganic fertilizer has no significant effect on leaves number, leaves length and leaves width of melon at 2 weeks after planting $(\mathrm{mst})$ to 5 mst.

Table 1.The Effect of Organic and Inorganic Fertilizer Combination on Melon Leaves

\begin{tabular}{|l|l|l|l|l|}
\hline \multirow{2}{*}{ Treatments } & \multicolumn{4}{|c|}{ Number of leaves (sheet) } \\
\cline { 2 - 5 } & 2 MST & 3 MST & 4 MST & 5 MS \\
\hline P0 & $2.9 \mathrm{a}$ & $5.8 \mathrm{a}$ & $14.6 \mathrm{a}$ & $23.3 \mathrm{a}$ \\
\hline P1 & $2.8 \mathrm{a}$ & $6.5 \mathrm{a}$ & $14.8 \mathrm{a}$ & $20 \mathrm{a}$ \\
\hline P2 & $2.5 \mathrm{a}$ & $5.6 \mathrm{a}$ & $12.7 \mathrm{a}$ & $17.4 \mathrm{a}$ \\
\hline P3 & $3.4 \mathrm{a}$ & $9.0 \mathrm{a}$ & $19.7 \mathrm{a}$ & $31 \mathrm{a}$ \\
\hline P4 & $2.8 \mathrm{a}$ & $6.3 \mathrm{a}$ & $16.6 \mathrm{a}$ & $25.6 \mathrm{a}$ \\
\hline
\end{tabular}

Description: The numbers followed by the same letter in the same column were not significantly different based on the BNJ test at the $5 \%$ level

Table 1 indicated that the effect of the combination of organic and inorganic fertilizers on the number of melon leaves was not significantly different in each treatment. The highest yield was obtained at treatment of P3 (combination of chicken manure with NPK 50\%) at age 2 mst to 5 mst with successive result $3,4,9,0,19,7$ and 31 strands. The lowest yield on treatment of P2 (combination of cow manure with NPK 50\%) at ages 2 mst to 5 mst with consecutive results $2.5,5.0,12.7$ and 17.4 leaf.

Table 2. The Effect of Organic and Inorganic Fertilizer Combination on Length of Melon Leaves

\begin{tabular}{|l|l|l|l|l|}
\hline \multirow{2}{*}{ Treatment } & \multicolumn{4}{|c|}{ Length of leaves (cm) } \\
\cline { 2 - 5 } & 2 MST & 3 MST & 4 MST & 5 MST \\
\hline P0 & $4.61 \mathrm{a}$ & $6.1 \mathrm{a}$ & $8.39 \mathrm{a}$ & $9.56 \mathrm{a}$ \\
\hline P1 & $4.98 \mathrm{a}$ & $6.66 \mathrm{a}$ & $8.02 \mathrm{a}$ & $8.53 \mathrm{a}$ \\
\hline P2 & $4.57 \mathrm{a}$ & $6.36 \mathrm{a}$ & $7.67 \mathrm{a}$ & $8.61 \mathrm{a}$ \\
\hline P3 & $5.97 \mathrm{a}$ & $7.88 \mathrm{a}$ & $9.7 \mathrm{a}$ & $10.15 \mathrm{a}$ \\
\hline P4 & $4.65 \mathrm{a}$ & $7.12 \mathrm{a}$ & $8.1 \mathrm{a}$ & $8.9 \mathrm{a}$ \\
\hline
\end{tabular}

Description: The numbers followed by the same letter in the same column were not significantly different based on the BNJ test at the $5 \%$ level. 
Table 2 indicated that the effect of organic and inorganic fertilizer combination on melon leaves length was not significantly different in each treatment. The highest result was obtained on P3 treatment at age $2 \mathrm{mst}$ to $5 \mathrm{mst}$ with successive result $5,97,7,88,9,7,10$, and $15 \mathrm{~cm}$. The lowest result was at age 2 and 4 mst on P2 treatment with leaves length 4.57 and $7.67 \mathrm{~cm}$, while at age $3 \mathrm{mst}$ that was treatment of P0 (NPK 100\%) with leaves length $6.1 \mathrm{~cm}$ and at age $5 \mathrm{mst}$, leaves length was at treatment P1 ( combination of goat manure with $50 \%$ NPK) with leaves length of $8.53 \mathrm{~cm}$.

Table 3. Influence of Organic and Inorganic Fertilizer Combination on Melon Leaves

\begin{tabular}{|l|l|l|l|l|}
\hline \multirow{2}{*}{ Treatment } & \multicolumn{4}{|c|}{ Length of leaves (cm) } \\
\cline { 2 - 5 } & 2 MST & 3 MST & 4 MST & 5 MST \\
\hline P0 & $6.18 \mathrm{a}$ & $8.67 \mathrm{a}$ & $12.40 \mathrm{a}$ & $14.12 \mathrm{a}$ \\
\hline P1 & $6.13 \mathrm{a}$ & $9.54 \mathrm{a}$ & $11.35 \mathrm{a}$ & $12.40 \mathrm{a}$ \\
\hline P2 & $5.89 \mathrm{a}$ & $8.67 \mathrm{a}$ & $11.22 \mathrm{a}$ & $12.78 \mathrm{a}$ \\
\hline P3 & $7.73 \mathrm{a}$ & $11.48 \mathrm{a}$ & $13.67 \mathrm{a}$ & $14.80 \mathrm{a}$ \\
\hline P4 & $5.76 \mathrm{a}$ & $8.70 \mathrm{a}$ & $11.49 \mathrm{a}$ & $13.05 \mathrm{a}$ \\
\hline
\end{tabular}

Description: The numbers followed by the same letter in the same column were not significantly different based on the BNJ test at the $5 \%$ level.

Table 3 indicated the effect of combination of organic and inorganic fertilizer on leaves width was not significantly different at age $2 \mathrm{mst}$ to $5 \mathrm{mst}$. The widest leaves result was obtained at treatment P3 at age 2 mst to 5 mst with successive number of $7.73,11.48,13.67$ and $14.80 \mathrm{~cm}$. The result of narrowed leaves was at treatment of $\mathrm{P} 2$ at age 2 mst and 4 mst that was 5.98 and $11.22 \mathrm{~cm}$, while at age 3 mst narrowed leaves existed in treatment of P0 and P2 and got same number that was $8,67 \mathrm{~cm}$, while at age $5 \mathrm{mst}$, treatment of $\mathrm{P} 2$ had width Leaves $12.40 \mathrm{~cm}$.

\subsection{Production}

Based on the result of the analysis, the combination of organic and inorganic fertilizers did not significantly affect the first flowering time, fruit circumference and fruit sugar content but significantly effect to melon fruit weight.

Table 4. Effects of Organic and Inorganic Fertilizer Combinations on Melon Production Components

\begin{tabular}{|l|l|l|l|l|}
\hline Treatment & $\begin{array}{c}\text { Flower } \\
\text { Time } \\
\text { First } \\
\text { (day) }\end{array}$ & $\begin{array}{c}\text { Weight } \\
\text { of fruit } \\
\text { (g) }\end{array}$ & $\begin{array}{c}\text { Fruit } \\
\text { Round } \\
\text { (cm) }\end{array}$ & $\begin{array}{c}\text { Fruit } \\
\text { Sugar } \\
\text { Level } \\
\text { (brix) }\end{array}$ \\
\hline P0 & $20.6 \mathrm{a}$ & $0.5 \mathrm{a}$ & $0.5 \mathrm{a}$ & $0.5 \mathrm{a}$ \\
\hline P1 & $20.2 \mathrm{a}$ & $55.6 \mathrm{a}$ & $4.7 \mathrm{a}$ & $0.5 \mathrm{a}$ \\
\hline P2 & $20.6 \mathrm{a}$ & $0.5 \mathrm{a}$ & $0.5 \mathrm{a}$ & 0.5 \\
\hline P3 & $20 \mathrm{a}$ & $42.85 \mathrm{a}$ & $2.75 \mathrm{a}$ & $0.85 \mathrm{a}$ \\
\hline P4 & $20.2 \mathrm{a}$ & $296.61 \mathrm{~b}$ & $5.41 \mathrm{a}$ & $1.11 \mathrm{a}$ \\
\hline
\end{tabular}

Description: The numbers followed by the same letter in the same column are not significantly different based on the BNJ test at the $5 \%$ level.

Table 4 indicated that the effect of the combination of organic and inorganic fertilizers on the first flower time, fruit circumference and fruit sugar content were not significantly different in each treatment except on the $n$ fruit weight. The first average flower time at the age of 20 days, with the fastest interest time was on the treatment of $\mathrm{P} 3$ while the time of the slowest interest was on P0 and P2 with 20.6 days. The weight of the heaviest melon fruit was obtained in the P4 treatment of $296.91 \mathrm{~g}$ and the lightest melon fruit weight on the treatment of P0 and P2 was 0.5 $\mathrm{g}$. The largest fruit circle in $\mathrm{P} 4$ treatment was $5.41 \mathrm{~cm}$ and the smallest fruit circle in the treatment of P0 and P2 was $0.5 \mathrm{~cm}$. The highest melon sugar content in the $\mathrm{P} 4$ treatment was 1.11 brix and the lowest sugar content in treatment $\mathrm{P} 0, \mathrm{P} 1$ and $\mathrm{P} 2$ was 0.5 brix.

\section{Discussion}

The effect of the combination of organic and inorganic fertilizer on the growth and production of melon plants could be seen in the variables of leaves number, leaves length, leaves width, first flowering time, fruit weight, fruit circumference and fruit sugar content. The results of the research have indicated that the combination of organic and inorganic fertilizers had no significant effect on the observed variables. In general, the combination of chicken manure with $50 \%$ NPK gave the highest yield on leaves number, leaves length and leaves width but not significantly different with other treatments. This proved that the application of chicken manure was able to improve soil fertility so that NPK fertilizer could be absorbed properly by the plant. The application of organic fertilizer combined with inorganic fertilizer could improve soil productivity and efficiency of fertilizer use [2]. This statement, however, was not in line with the results of research showing that the combination of cow manure with $50 \%$ NPK gave the lowest yield on the number of leaves and leaves length. This was presumably because the nutrients contained in the combination of cow manure with NPK $50 \%$ was still not enough to meet the needs of plants so that leaves grew slightly with the length and width of small leaves. Cow manure has a $\mathrm{C} / \mathrm{N}$ ratio of $>40$. High levels of $\mathrm{C}$ in cow manure inhibit direct use to agricultural land because it would suppress the growth of main crops. Growing emphasis occured because decommissioner microbes would use the available $\mathrm{N}$ to decompose the organic material, so the main plant would lack $\mathrm{N}$ [5]. Differences in the number of leaves, leaves length and leaves width resulting from the diversity of the combination of organic fertilizer given to the plant. According [6], leaves formation in a plant other than influenced by environmental conditions such as nutrients was also influenced by the ability of leaves area in a plant to increase the number of leaves.

The combination of organic and inorganic fertilizers did not significantly affect the time of the first melon flowers. The first flower time averages 20 days after planting, with the earliest first time of interest in the combination treatment of chicken manure with NPK $50 \%$. Each experimental plant at each treatment was flowering perfectly at an average age of 20-21 hst. However, at the time of flowering the rain occurs continuously so that the flowers and fruit would fall out. Flower on plant with combination treatment of cow manure with $50 \%$ NPK, combination of chicken manure with NPK 50\% and combination of compost with NPK $50 \%$ which become fruit, while the plant was given $100 \%$ NPK fertilizer and combination of cow manure with NPK 50\% falls fruit 
before the harvest time. This cauld happen because in the period of fruit development undergoes continuous rain within three days. The fall fruit is also suspected because the available nutrients are not enough for the fruit development.

The physiological fail of flower and fruit correlated with the limited supply of fotosintat and nutrient sufficiency [7]. The plants given $100 \%$ NPK only had elements $\mathrm{N}, \mathrm{P}, \mathrm{K}$ and did not have other nutrients needed by plants. The combination of cow manure with $50 \% \mathrm{NPK}$ falls fruit because the available nutrients were not sufficient for the fruit development process. Cow manure contains organic matter $16 \%, \mathrm{~N} 0.3 \%, \mathrm{P} 2 \mathrm{O} 50.2 \%, \mathrm{~K} 2 \mathrm{O}$ $0.15 \%$ and $\mathrm{CaO} 0.2 \%$ [5]. Low $\mathrm{P}$ content in cow manure could not meet the needs of the plants given $\mathrm{P}$ fertilizer $50 \%$ of the recommended dose. The function of phosphorus $(\mathrm{P})$ in the plant was to stimulate root growth, especially the roots of young seeds/plants. Accelerate and strengthen the growth of young plants into adult plants and increase the percentage of flowers into fruit, assisting assimilation and breathing as well as accelerate flowering and ripening fruit. Posfor $(\mathrm{P})$ had a nutrient translocation function of plants. In metabolism, cell phosphate ester had direct function related to cell energy, phosphorus was a compound of plant tissue like nucleic acid, phospholipid and fitin. $\mathrm{P}$ was needed for the formation of primordia flowers and plant organs for reproduction, the other role of $\mathrm{P}$ is to speed up the fruit ripening [8].

The combination of compost fertilizer with NPK $50 \%$ gave the highest yield on fruit weight and significantly different from other treatment and give the highest yield on fruit circumference and fruit sugar content but not significantly different from other treatments. This was because the combination of both available nutrients was high for plants compared with other treatments. The compost increases potassium levels in soil higher than potassium provided by NPK [9]. The compost fertilizer could increase nutrient availability for the plant because the composting process to change the form of nutrients that were not available becomes easily available and improved the physical, chemical and biological soil fertility [5].

The combination of compost fertilizer with NPK $50 \%$ gave the highest result on the value of fruit sugar content but not significantly different from other treatment. This happened because the nutrients in this combination were available at most compared to other treatments. The fruit sugar content was influenced by $\mathrm{K}$ and $\mathrm{Mg}$ available in the soil [10]. Nutrients were absorbed by plants to meet the needs of metabolism in composing skeletal plants, especially in the increase in fruit sugar levels and quality of melon fruit. Plants absorbed $\mathrm{K}$ and $\mathrm{Mg}$ cations by exchanging other cations whose valence was the same and its presence was abundant in the plant body. Potassium was needed for enzyme activity and helped to close the stomatal closure. Potassium also served to assist in the process of translocating the sugar of photosynthesis throughout the body parts of plants and storage places. The absorbed magnesium of the plant served to construct chlorophyll and as an important component in various enzymes [8].

\subsection{Conclusion}

1. The combination of organic and inorganic fertilizers significant effect on melon fruit weight but not significant effect on leaves number, leaves length, leaves width, first flower time, fruit circumference and fruit sugar content.

2. The combination of chicken manure with $50 \%$ NPK gave the highest yield on leaves number, leaves length, leaves width and first flower melon time but not significantly different from other treatments.

3. The combination of compost fertilizer with NPK $50 \%$ gave the highest yield on melon fruit weight and significantly different from other treatments.

4. The combination of compost fertilizer with NPK 50\% gave the highest yield on fruit circumference and melon fruit sugar but not significantly different from other treatments.

\section{References}

[1] Ammar and Astuti, P. 2012. Pola Peningkatan Produksi Melon dengan Penggunaan Pupuk Organik Cair. Faculty of Agriculture, Sriwijaya University.

[2] Sugito. 2013. Petunjuk Praktis Budidaya Melon dalam Pot. Balai Pengkajian Teknologi Pertanian Kepulauan Bangka Belitung Badan Litbang Pertanain Kementrian Pertanian. Retrieved from www.babel.litbang.pertanian.go.id [23 August 2015].

[3] BPS. 2014. Produksi Buah di Indonesia. Direktorat Jenderal Hortikultura. Kementrian Pertanian. Retrieved from http://www.horti.pertanian.go.id [9 July 2015].

[4] Lingga. 2013. Peningkatan Produktifitas Melon secara Hidroponik dirumah Kaca. Faculty of Agriculture, Lampung University. Retrieved from www.digilib.unila.ac.id [7 August 2015].

[5] Wiwik H. and Widowati, L.R. 2006. Pupuk Hayati dan Pupuk Organik. Balai Penelitian Tanah. Balai Besar Penelitian dan Pengembangan Sumber Daya Lahan Pertanian. Bogor.

[6] Bagus N.R. 2015. Pengaruh Pemberian Beberapa Pupuk Organik Padat terhadap Pertumbuhan dan Hasil Cabai Merah, Bawang Merah dan Bawang Daun. Gontor Agrotech Science Jounal 1(2): 53-70.

[7] Marchner, H. 1986. Material Nutrition in Higher Plants. Second edition. London : Academic press.

[8] Wijaya, K.A. 2008. Nutrisi Tanaman sebagai Penentu Kualitas Hasil dan Resistensi Alami Tanaman. Jakarta: Prestasi Pustaka.

[9] Abdurohim, O. 2008. Pengaruh Kompos Terhadap Ketersediaan Hara dan Produksi Tanaman Caisin Pada Tanah Latosol Dari Gunung Sindur. Faculty of Agriculture, Bogor Agricultural University. Retrieved from www.repository.ipb.ac.id [2 November 2015].

[10] Siswanto. 2010. Meningkatkan Kadar Gula Buah Melon. Jawa Timur: UPN Veteran. 